\title{
PENERAPAN METODE TIME AND MATERIAL PRICING SEBAGAI DASAR PENENTUAN HARGA JUAL JASA PADA PT. SINAR GALESONG MANDIRI MALALAYANG MANADO
}

\author{
Enjelin Lolong ${ }^{1}$, Ventje Ilat ${ }^{2}$, Victorina Tirayoh $^{3}$ \\ ${ }^{1,2,3}$ Jurusan Akuntansi, Fakultas Ekonomi dan Bisnis, Universitas Sam Ratulangi, Jl. Kampus Bahu, Manado, \\ 95115, Indonesia \\ E-mail : enjelinlolong@gmail.com
}

\begin{abstract}
Determination of selling prices can be done with several approaches, one of which is the cost approach can identify the amount of costs that have been incurred to produce a product or service. This research was conducted at PT. Sinar Galesong Mandiri Malalayang Manado having its address at Malalayang, North Sulawesi. The purpose of this study is to apply the Time and Material Pricing Method in determining the selling price of services in the workshop of PT. Sinar Galesong Mandiri Malalayang Manado. The method of analysis uses quantitative descriptive data analysis methods, described direct costs and indirect costs, as well as analyzing and comparing a situation so that conclusions can be drawn which include the application of the Time and Material Pricing Method as a basis for determining selling prices. The results of the study illustrate that the selling price set by PT. Sinar Galesong Mandiri Malalayang Manado for the workshop is still not appropriate, because in the calculation of the selling price of the service does not take into account the costs incurred by the company. Selling price of the service, so that the price is relatively cheap, will later increase the motor entry unit and will also increase sales volume.
\end{abstract}

Keywords: selling price; time and material pricing; mark up; direct cost; indirect cost

\section{PENDAHULUAN}

Perusahaan sebagai suatu entitas ekonomi didirikan dengan maksud untuk melaksanakan serangkaian aktifitas dan kegiatan yang bersifat ekonomi, dan diharapkan dapat memperoleh suatu hasil akhir yang menguntungkan bagi pihak-pihak yang berkepentingan atas perusahaan tersebut. Perusahaan memerlukan penentuan harga jual yang tepat kepada konsumen, sehingga tidak mengalami kerugian dengan biaya-biaya yang telah dikeluarkan oleh perusahaan dan mencapai profit yang diharapkan (Pontoh dan Budiarso, 2018).

Penentuan harga berkaitan erat dengan seluruh aspek kegiatan perusahaan.Penentuan harga jual berpengaruh kepada volume penjualan atau jumlah pembeli berpengaruh kepada jumlah pendapatan perusahaan. Jika harga jual terlalu tinggi akan menurunkan volume penjualan yang berakibat turunnya pendapatan perusahaan, begitu pula sebaliknya jika harga jual ditetapkan terlalu rendah akan mengakibatkan kerugian bagi perusahaan. Dengan kata lain kebijakan dalam penentuan harga tidak hanya ditujukan untuk menutupi biaya-biaya yang telah dikeluarkan tetapi juga dapat memberikan jaminan adanya laba bagi perusahaan.

Penentuan harga jual dilihat dari permintaan dan penawaran biasanya menjadi faktor pertimbangan tetapi biaya menjadi faktor yang memiliki tingkat kepastian yang relatif lebih tinggi dan berpengaruh jika dibandingkan dengan dua hal tersebut. Hal ini dikarenakan biaya dapat memberikan informasi batas bawah suatu harga jual, sehingga informasi terhadap biaya menjadi penting bagi manajer agar dapat mengambil keputusan harga jual yang tepat.

Penentuan harga jual dapat dilakukan dengan beberapa pendekatan, salah satunya adalah pendekatan biaya. Dengan pendekatan ini dapat mengindentifikasikan besarnya biaya 
yang telah dikeluarkan untuk menghasilkan produk atau jasa. Penentuan harga jual dengan pendekatan biaya menggunakan informasi biaya penuh karena dapat memberikan informasi yang dibutuhkan manajemen dalam pengambilan keputusan. Jika harga jual yang ditetapkan dibawah biaya penuh produk atau jasa akan mengakibatkan kerugian perusahaan. Kerugian yang ditimbulkan tersebut dalam jangka waktu tertentu mengakibatkan perusahaan bangkrut.

PT. Sinar Galesong Mandiri Malalayang Manado merupakan perusahaan yang bergerak dibidang dealer motor dalam hal ini pelayanan servis khusus motor Suzuki, selain pelayanan jasa servis motor. PT. Sinar Galesong Mandiri Malalayang juga menjual spare part atau suku cadang, yang nantinya akan digunakan untuk penggantian suku cadang sepeda motor yang akan diservis, sehingga konsumen tidak perlu mencari suku cadang yang akan diganti di komponen motornya. Walaupun motor Suzuki ada berbagai macam tipe yaitu tipe Cub, Matic, dan Sport tetapi semua jenis tipe motor, spare part atau suku cadangnya tersedia. Perhitungannya sudah ditetapkan oleh PT. Sinar Galesong Mandiri Malalayang dalam penentuan harga jual jasa servis dan bahan perhitungannya tidak jauh berbeda dengan bengkel lainnya yang hanya menambahkan berapa besar laba yang diinginkan oleh perusahaan dalam menentukan harga jual atau dijual kembali.

Perhitungan yang dilakukan atau yang dipakai oleh PT. Sinar Galesong Mandiri Malalayang belum tepat, karena dalam perhitungan harga jual jasa tersebut, tidak memperhitungkan biaya-biaya yang telah dikeluarkan oleh bengkel, karena hanya mengikuti kebijakan yang telah dikeluarkan oleh Principle PT. Sinar Galesong Mandiri Malalayang selain itu perusahaan juga tidak memperhitungkan tentang aktiva yang digunakan dalam melakukan jasa servis dari penjualan spare part atau suku cadang.

\section{TINJAUAN PUSTAKA}

Pengertian Akuntansi. Menurut Giri (2012:4), akuntansi dari tiga sudut pandang, yaitu sebagai (1) kegiatan jasa, (2) bidang studi, dan (3) proses atau kegiata. Sebagai kegiatan jasa, akuntansi merupakan kegiatan jasa penyediaan informasi (kuantitatif dan kualitatif) mengenai unit - unit usaha ekonomi, terutama yang bersifat keuangan yang bermanfaat dalam pengambilan keputusan ekonomi. Firdaus (2012:3) berpendapat bahwa Akuntansi adalah sebagai suatu sistem informasi yang memberikan laporan kepada berbagai pemakai atau pembuat keputusan mengenai aktivitas bisnis dari suatu kesatuan ekonomi atau dapat pula dinyatakan bahwa akuntansi adalah "bahasa bisnis" karena akuntansi berfungsi sebagai media komunikasi dari informasi bisnis. Dalam akuntansi menurut Rudianto (2013:4) mendefinisikan Akuntansi Manajemen merupakan sistem alat, yakni jenis informasi yang dihasilkan ditunjukan kepada pihak-pihak internal organisasi, seperti manajer keuangan, manajer produksi, manajer perusahaan dan sebagainya guna pengambilan keputusan internal organisasi. Harahap (2011 : 10) Akuntansi diartikan sebagai berikut :Proses mengidentifikasikan, mengukur, dan menyampaikan informasi ekonomi sebagai bahan informasi dalam hal mempertimbangkan berbagai alternative dalam mengambil kesimpulan oleh para pemakainya

Konsep Akuntansi Biaya. Pengertian akuntansi biaya menurut Bastian, et al. (2016 : 2), "Akuntansi biaya adalah suatu bidang akuntansi yang mempelajari bagaimana cara mencatat, mengukur, dan melaporkan tentang informasi biaya yang digunakan".Menurut Horngren, et al. (2008:3), "Akuntansi Biaya menyediakan informasi yang dibutuhkan untuk akuntansi manajemen dan akuntansi keuangan. Akutantansi biaya mengukur dan melaporkan setiap informasi keuangan dan non keuangan yang terkait dengan biaya perolehan atau pemanfaatan sumber daya dalam suatu organisasi.Menurut Schaum yang diterjemahkan oleh Mursyidi (2009: 2), "Akuntansi biaya adalah suatu bidang akuntansi yang diperuntukkan bagi proses pelacakan, pencatatan, dan analisa terhadap biaya-biaya yang berhubungan dengan aktivitas suatu organisasi untuk menghasilkan barang atau jasa.Menurut Mulyadi (2012:8) 
dalam arti luas biaya adalah pengorbanan sumber ekonomi, yang diukur dalam satuan uang, yang telah terjadi atau yang kemungkinan akan terjadi untuk tujuan tertentu.Dari beberapa definisi di atas dapat disimpulkan :

1. Kegiatan akuntansi terdiri dari pencatatan, penggolongan, dan penyajian laporan keuangan harus dibuktikan dengan adanya dokumen yang dipakai sebagai dasar pencatatan dan penggolongan.

2. Disamping itu, akuntansi biaya juga membahas tentang penentuan harga pokok dari "suatu produk" yang diproduksi dan dijual di pasar baik guna memenuhi keinginan pemesan maupun menjadi persediaan barang dagangan yang akan dijual.

3. Akuntansi biaya berfungsi untuk mengukur nilai masukan atau nilai awal guna untuk menghasilkan informasi bagi manajemen yang salah satu manfaatnya untuk menetapkan harga jual dan dapat mengukur apakah kegiatan usahanya menghasilkan laba atau tidak.

Menurut Prawironegoro, et al. (2016:49) Biaya adalah kas dan setara kas yang dikorbankan untuk memproduksi atau memperoleh barang atau jasa yang diharpkan akan memperoleh atau keuntungan dimasa mendatang.

Peranan Akuntansi Biaya. Akuntansi biaya melengkapi manajemen dengan alat yang diperlukan untuk aktivitas-aktivitas perencanaan dan pengendalian, memperbaiki kualitas dan efisiensi, serta membuat keputusan-keputusan yang bersifat rutin maupun strategis.

Carter (2009:15) menyatakan, "peranan akuntansi biaya adalah membantu manajemen dalam menyelesaikan tugas-tugas berikut:

1. Membuat dan melaksanakan rencana dan anggaran untuk operasi dalam kondisikondisi kompetitif dan ekonomi yang telah diprediksikan sebelumnya.

2. Menetapkan metode perhitungan biaya dan prosedur yang menjamin adanya pengendalian dan jika memungkinkan pengurangan biaya atau adanya pembebanan biaya dan perbaikan mutu.

3. Mengendalikan kuantitas fisik dari persediaan, dan menentukan biaya dari setiap produk dan jasa yang dihasilkan, untuk tujuan penetapan harga dan evaluasi kinerja dari suatu produk, departemen, atau divisi.

4. Menentukan biaya dan laba perusahaan untuk satu tahun periode akuntansi atau untuk periode lain yang lebih pendek. Hal ini termasuk menentukan nilai persediaan dan harga pokok penjualan sesuai dengan aturan pelaporan eksternal.

5. Memilih diantara dua atau lebih alternative jangka pendek atau jangka panjang, yang dapat mengubah pendapatan atau biaya.

Manfaat Akuntansi Biaya. Menurut Witjaksono (2006 : 4) manfaat akuntansi biaya, antara lain :

1. Menimbulkan sifat "sadar akan biaya" (cost awareness)

2. Sebagai tolak ukur pengelolaan biaya sehingga mampu mengukur biaya dengan cukup akurat serta didukung kemampuan manajemen untuk memanfaatkan informasi yang dihasilkan.

3. Sebagai pemasok informasi dasar untuk menentukan harga jual produk barang dan jasa.

4. Sebagai bagian dari alat pengendalian manajemen, terutama yang berkaitan dengan pengukuran kinerja manajer pusat pertanggungjawaban.

5. Sebagai pemasok informasi pada pihak eksternal berkenaan dengan seluruh aspek biaya operasi, misalnya untuk kepentingan pajak.

Mursyidi (2009:55), Manfaat Akuntansi biaya yaitu:

1. Menyediakan salah satu informasi yang diperlukan oleh manajemen dalam mengelola perusahaannya. 
2. Sebagai perencaaan dan pengendalian laba

3. Sebagai penentuan harga pokok produk dan jasa

4. Serta bagi pengambilan keputusan oleh manajemen

Perilaku Biaya. Menurut Mulyadi (2012:465) pada umumnya pola perilaku biaya diartikan sebagai hubungan antara total biaya dengan perubahan volume kegiatan. Berdasar perilakunya dalam hubungannya dengan perubahan volume kegiatan, biaya dapat dibagi menjadi tiga golongan :

1. Biaya tetap

Untuk keperluan perencanaan dan pengendalian harus dipecah lagi sebagai berikut :

a.Committed fixed cost sadalah sebagian besar berupa biaya tetap yang timbul dari pemilikan pabrik, ekuipmen dan organisasi pokok, perilaku committed fixed cost ini dapat diketahui dengan jelas dengan mengamati biaya-biaya yang tetap dikeluarkan jika seandainya perusahaan tidak melakukan kegiatan sama sekali dan akan kembali ke kegiatan normal, contoh : biaya depresiasi, pajak bumi dan bangunan, sewa, asuransi dan gaji karyawan utama.

b.Discretionary fixed cost yaitu yang timbul dari keperluan penyediaan anggaran secara berkala (biasanya tahunan) yang secara langsung mencerminkan kebijakan manajemen puncak mengenai jumlah maksimum biaya yang diijinkan untuk dikeluarkan. Yang tidak dapat menggambarkan hubungan yang optimum antara masukan dengan keluaran. Contoh Discretionary fixed costs adalah biaya riset dan pengembangan, biaya iklan, biaya promosi penjualan, biaya program latihan karyawan, biaya konsultasi.

2. Biaya variabel

Untuk keperluan perencanaan dan pengendalian dipecah lagi sebagai berikut:

a.Engineered variable costs adalah biaya yang memiliki hubungan fisik tertentu dengan ukuran kegiatan tertentu, contoh: biaya bahan baku.

b.Discretionary variable costs merupakan biaya yang masukan dan keluarannya memiliki hubungan erat namun tidak nyata (bersifat artificial), jika keluaran berubah maka masukan berubah, keluaran belum tentu berubah dengan adanya perubahan masukan tersebut.

3. Biaya semivariabel

Biaya semivariabel adalah biaya yang memiliki unsur tetap dan variabel didalamnya, unsur biaya yang tetap merupakan jumlah biaya minimum untuk menyediakan jasa sedangkan unsur variabel merupakan bagian dari biaya semi variabel yang dipengaruhi oleh perubahan volume kegiatan.

Konsep Penentuan Harga Jual. Pengertian Harga Jual menurut Kotler, et al (2004:439), mendefinisikan harga jual adalah sejumlah uang yang dibebankan atas suatu produk atau jasa, atau jumlah dari nilai yang ditukar konsumen atas manfaat-manfaat, karena memiliki atau menggunakan produk atau jasa tersebut. Menurut Mulyadi (2001 : 78) " pada prisipnya harga jual harus dapat menutupi biaya penuh ditambah dengan laba yang wajar. Harga jual sama dengan biaya produksi ditambah mark-up". Dari definisi di atas dapat disimpulkan bahwa harga jual adalah sejumlah biaya yang dikeluarkan perusahaan untuk memproduksi suatu barang atau jasa ditambah dengan persentase laba yang diinginkan perusahaan, karena itu untuk mencapai laba yang diinginkan oleh perusahaan salah satu cara yang dilakukan untuk menarik minat konsumen adalah dengan cara menentukan harga yang tepat untuk produk yang terjual. Harga yang tepat adalah harga yang sesuai dengan kualitas produk suatu barang dan harga tersebut dapat memberikan kepuasan kepada konsumen.

Sasaran Penetapan Harga Jual. Para pemasar berusaha untuk mencapai sasaran tertentu melalui komponen-komponen penetapan harga. Beberapa perusahaan mencoba untuk meningkatkan keuntungan dengan menetapkan harga rendah untuk menarik bisnis baru. 
Menurut Boone, et al (2013:70) " ada empat kategori dasar atau sasaran penetapan harga, yaitu : 1) profitabilitas, 2) volume, 3) tingkat kompetisi, dan 4) pretise".

1. Sasaran profitabilitas

Sebagian besar perusahaan mengejar sejumlah sasaran profitabilitas dalam strategi penetapan harganya.Para pemasar mengerti bahwa laba diperoleh dari selisih pendapatan dan beban.Dan juga pendapatan merupakan harga jual dikalikan dengan jumlah yang terjual.Berbagai teori ekonomi mendasari prinsip maksimalisasi keuntungan (profit maximization). Akan tetapi pada kenyataannya prinsip ini masih sulit diterapkan.Maka banyak perusahaan beralih pada sasaran profitabilitas yang lebih sederhana, yaitu Target Return Goal, dimana perusahaan menetapkan harga dengan tingkat profitabilitas yang diinginkan sebagai pengembalian financial atas penjualan ataupun investasi.

2. Sasaran volume

Pendekatan yang lain dalam strategi penetapan harga disebut maksimalisasi penjualan (sales maximization), para manajer menetapkan tingkat minimum profitabilitas yang dapat diterima dan kemudian menetapkan harga yang akan menghasilkan volume penjualan tertinggi tanpa menyebabkan laba turun di bawah level itu. Strategi ini memandang ekspansi penjualan sebagai suatu prioritas yang lebih penting bagi posisi persaingan jangka panjang perusahaan daripada laba jangka pendek.

3. Tingkat Kompetisi

Sasaran penetapan harga ini hanyalah untuk menyamakan harga dengan pesaing.Jadi perusahaan berusaha untuk menghindari perang harga dengan tidak menekankan elemen harga dari bauran pemasaran dan memfokuskan usaha persaingannya pada variable selain harga seperti menambah nilai, meningkatkan kualitas, mendidik konsumen, dan menciptakan hubungan.

4. Sasaran Prestise

Pengaruh harga pada prestise membuat sebuah harga menjadi relatife tinggi untuk mengembangkan dan menjaga sebuah citra dari kualitas dan ekslusivitas.Para pemasar menetapkan sasaran tersebut karena mereka mengakui peran harga dalam mengkomunikasikan citra suatu perusahaan dan produk-produknya.

Metode Penentuan Harga Jual . Menurut Swasta (2010:154) metode penentuan harga jual yang dalam bentuk sederhana yaitu :

a) Cost plus pricing method

Penentuan harga jual cost plus pricing, biaya yang digunakan sebagai dasar penentuan. Dapat didefinisikan sesuai dengan metode penentuan harga pokok produk yang digunakan.

b) Mark up pricing method

Mark pricing banyak digunakan oleh para pedagang. Para pedagang akan menentukan harga jualnya dengan cara menambahkan Mark up yang diinginkan pada harga beli per satuan.

c) Penentuan harga oleh produsen

Dalam metode ini, harga yang ditetapkan oleh produsen adalah awal dari rangkaian harga yang ditetapkan oleh perusahaan-perusahaan lain dalam saluran distribusi.

Metode Time and Material Pricing. Penentuan harga jual waktu dan bahan ini pada dasarnya merupakan cost plus pricing. Harga jual ditentukan sebesar biaya penuh ditambah dengan laba yang diharapkan. Metode penentuan harga ini digunakan oleh perusahaan bengkel mobil, motor, dok kapal dan lainnya yang menjual jasa reparasi bahan dan suku cadang.Volume jasa dihitung berdasarkan waktu yang diperlukan untuk melayani pelanggan, sehingga perlu dihitung harga jual per satuan waktu yang dinikmati oleh pelanggan. Sedangkan volume bahan dan suku cadang yang diperlukan sebagai pelengkap penyerahan 
dihitung berdasarkan kuantitas bahan dan suku cadang yang diberikan kepada pelanggan.Penentuan harga jual waktu dan bahan dibagi menjadi 2 yaitu :

a) Harga jual waktu : yaitu menghitung berapa harga jual waktu dalam proses perbaikan.

\begin{tabular}{|c|c|c|}
\hline Harga Jual & $=$ & Biaya TKL + Mark Up \\
\hline Mark up & $=$ & $\begin{array}{l}\text { Biaya tidak langsung + laba yang diharapkan } \\
\text { Biaya tenaga kerja langsung }\end{array}$ \\
\hline Biaya TKL & $=$ & $\begin{array}{l}\text { Upah TKL + Biaya kesejahteraan } \\
\text { Jumlah kerja TKL satu tahun anggaran }\end{array}$ \\
\hline
\end{tabular}

b) Harga jual bahan : yaitu menghitung berapa biaya dikeluarkan oleh perusahaan dalam memperoleh bahan.

Harga Jual = Harga beli bahan dan suku cadang + Mark Up

Mark Up = Biaya tidak langsung + laba yang diharapkan

Nilai bahan \$ SC yang akan dibeli 1 tahun anggaran

\section{METODE PENELITIAN}

Jenis data yang dipergunakan dalam penelitian ini, yaitu:

1. Data Kualitatif, yaitu data yang disajikan secara deskriptif untuk mengetahui atau menggambarkan situasi yang terjadi dalam perusahaan adapun dengan melakukan wawancara sehinggah memudahkan penulis untuk mendapatkan data yang objektif dalam rangka memahami perilaku akuntansi terhadap badan produksi. Penelitian ini yaitu berupa gambaran umum perusahaan dan data pada objek penelitian

2. Data Kuantitatif, dalam bentuk angka - angka atau bilangan yang dapat dihitung dan dapat dibandingkan yang satu dengan yang lainnya. Data - data tersebut berupa daftar gaji pegawai tetap, perhitungan menggunakan metode time and material pricing.

Sumber Data

Sumber data dalam penelitian ini,yaitu :

1. Data Primer, data yang diperoleh langsung oleh penelitian dari objek penelitian yaitu PT. Sinar Galesong Mandiri Malalayang Manado dengan wawancara. Data yang diambil dalam penelitian ini berupa : Sejarah dan Profil PT. Sinar Galesong Mandiri Malalayang Manado beserta visi dan misi, struktur organisasi dan job description.

2. Data Sekunder, yaitu data yang berasal dari sumber atau pengamatan lain. Contohnya : buku - buku literatur yang digunakan sebagai acuan, dan jurnal penelitian.

Metode analisis data yang digunakan dalam penelitian ini adalah adalah metode deskriptif, yaitu membahas masalah dengan cara mengumpulkan, menguraikan, menghitung, dan membandingkan suatu keadaan serta menjelaskan suatu keadaan sehingga dapat ditarik kesimpulan yang meliputi penerapan metode time and material pricing sebagai dasar penentuan harga jual pada PT. Sinar Galesong Mandiri Malalayang Manado.

Metode Analisis Data.Metode analisis yang digunakan dalam penelitian ini adalah metode deskriptif. Metode analisis deskriptif merupakan metode yang digunakan untuk menggambarkan dan menganalisis suatu hasil penelitian tetapi tidak digunakan untuk membuat kesimpulan yang lebih luas

\section{HASIL PENELITIAN DAN PEMBAHASAN}

\subsection{Hasil Penelitian}

Dari hasil perhitungan dengan menggunakan Metode Time and Material Pricing maka didapat biaya tenaga kerja langsung per jam sebesar Rp. 18.458,- dengan Mark-up yang diperoleh dari bengkel dengan persentase 567\%. Dan untuk Mark-up yang diperoleh bahan dengan persentase $29.92 \%$.Dari hasil perhitungan Waktu dan Bahan untuk paket servis yaitu 
paket Servis Lengkap dengan harga jual sebesar Rp. 217.366,- Servis Ringan Rp. 149.593,dan untuk Ganti Oli Rp. 92.180,-.Dari hasil perhitungan dengan menggunakan perhitungan PT. Sinar Galesong Mandiri Malalayang maka didapat biaya tenaga kerja langsung per jam sebesar Rp. 250.000,- (kendaraan kecil) dan untuk Mark-up yang diperoleh bahan dengan persentase $11.15 \%$ hasil perhitungan Waktu dan Bahan untuk paket servis yaitu paket Servis Lengkap dengan harga jual sebesar Rp.303.583,-Servis Ringan sebesar Rp.193.083,-dan untuk Ganti Oli sebesar Rp.107.798,-

Tabel 1.Perbedaan perhitungan harga jual jasa dan bahan PT. Sinar Galesong Mandiri Malalayang dan Metode Time and Material Pricing

\begin{tabular}{llc}
\multicolumn{1}{c}{ Jenis } & Perusahaan & Metode TMP \\
\hline Servis Lengkap & Rp.303.583,- & Rp.217.366,- \\
Servis Ringan & Rp.193.083,- & Rp.149.593,- \\
Ganti Oli & Rp.107.798,-- & Rp. 92.180,- \\
\hline
\end{tabular}

Sumber :Data Olahan 2018

Dari hasil yang didapat baik menggunakan perhitungan bengkelPT. Sinar Galesong Mandiri Malalayang dan Metode Time and Material Pricing terdapat perbedaan dalam penetapan harga jual jasa servis yang dibebankan kepada konsumen. penetapan harga yang dikeluarkan oleh PT. Sinar Galesong Mandiri Malalayang terlalu mahal dibandingkan dengan menggunakan Metode Time and Material Pricing. PT. Sinar Galesong Mandiri Malalayang menitik beratkan pada klasifikasi kendaraan kecil dan besar dalam perbaikannya.Metode Time and Material Pricing menghitung semua biaya-biaya atau beban yang dikeluarkan oleh PT. Sinar Galesong Mandiri Malalayang, sehingga perhitungannya lebih akurat dan tepat dibandingkan menurut perhitungan perusahaan.

\subsection{Pembahasan}

Setiap perusahaan yang berorientasi laba tentunya mengharapkan untuk memperoleh laba yang wajar sesuai investasi yang ditanamkan.PT. Sinar Galesong Mandiri Malalayang sebagai salah satu perusahaan yang berorientasi laba juga mengharapkan dapat menghasilkan laba yang wajar sesuai di investasi.Salah satu faktor yang menentukan besar kecilnya laba yang diperoleh adalah harga jual.Penerapan metode harga jual yang tepat sanggup menyediakan informasi perkiraan perolehan laba.Salah satu metode harga jual yang lazim di gunakan pada perusahaan jasa reparsi yang menjual suku cadang atau bahan adalah metode harga jual waktu dan bahan. Penerapan metode harga jual waktu dan bahan pada PT. Sinar Galesong Mandiri Malalayang menghasilkan harga jual untuk jasa reparasi Rp.123.114 dan markup 29,92 \% untuk penjualan suku cadang atau bahan. Dibanding dengan harga jual yang lama yaitu Rp.250.000 perjam jasa reparasi untuk kendaraan kecil dan Rp.275.000 perjam jasa raparasi untuk kendaraan besar, maka tarif jasa yang baru lebih murah. Untuk harga jual bahan dan suku cadang dimana perusahaan menetapkan harga jual dengan rata-rata $11,15 \%$ dari harga pokoknya, dibanding dengan markup untuk harga jual yang baru terjadi peningkatan yaitu sebesar $18.77 \%$. 
Tabel 2. Perbandingan Pendapatan menurut Perhitungan Perusahaan dengan Metode Harga Jual Waktu dan Bahan Tahun 2018

\begin{tabular}{|c|c|c|c|}
\hline Uraian & $\begin{array}{c}\text { Hasil } \\
\text { Perhitungan dari } \\
\text { Perusahaan }\end{array}$ & $\begin{array}{l}\text { Metode Harga Jual } \\
\text { Waktu dan Bahan }\end{array}$ & Keterangan \\
\hline Penjualan Jasa Reparasi & Rp.3.237.300.000 & Rp. 2.946.507.944 & \\
\hline Penjualan Suku Cadang & Rp.1.278.225.000 & Rp. 1.494 .080 .000 & \\
\hline Penjualan Bahan & Rp.1.089.270.000 & Rp. 1.273.216.000 & \\
\hline Total Penjualan & Rp.5.604.795.000 & Rp. 5.713.803.944 & \\
\hline Total HPP & Rp.2.130.000.000 & Rp. 2.130.000.000 & \\
\hline Pendapatan Kotor & Rp.3.474.795.000 & Rp. 3.583.803.944 & \\
\hline Total Biaya & Rp.3.221.299.750 & Rp. 3.221.299.750 & \\
\hline Pendapatan Usaha & Rp. 253.495.250 & Rp. $\quad 362.504 .194$ & Rp.109.008.944 \\
\hline
\end{tabular}

Berdasarkan perhitungan diatas terlihat bahwa setelah penerapan metode harga jual waktu dan bahan pendapatan usaha sebesar Rp. 362.504.194,-terjadi peningkatan dibandingkan dengan perhitungan perusahaan sebesar Rp. 253.495.250 sehingga pendapatan meningkat sebesar Rp.109.008.944

\section{KESIMPULAN DAN SARAN}

\subsection{Kesimpulan}

Berdasarkan hasil penelitian dan pembahasan yang telah dilakukan dapat ditarik kesimpulan bahwa penerapan time and material pricing menghasilkan harga per jam jasa reparasi Rp. 123.114 dan mark up sebesar $29.92 \%$ untuk suku cadang dan bahan, berdasarkan harga jual ini laba yang diperoleh perusahaan sebesar Rp.362.504.194, sehingga laba yang dihasilkan perusahaan akan lebih besar dibandingkan dengan metode perhitungan yang ditetapkan perusahaan dengan harga per jam jasa reparasi Rp. 250.000. Harga jual suku cadang dan bahan ditetapkan oleh perusahaan dengan menaikkan rata - rata $11,15 \%$ di atas harga pokoknya dengan harga jual ini laba yang diperoleh perusahaan sebesar $\mathrm{Rp}$. 253.495.250

\subsection{Saran}

Saran bagi perusahaan berdasarkan pembahasan dari penelitian ini yaitu :

1. Perusahaan sebaiknya menerapkan metode time and material pricing dalam menentukan harga jualnya karena perhitungsn dengan metode ini menghasilkan laba yang lebih besar dibandingkan dengan metode yang digunakan perusahaan.

2. Diusahakan adanya peningkatan penggunaan kapasitas jam jasa reparasi/peningkatan volume penjualan jasa reparasi yang dapat dicapai melalui penerapan metode time and material pricing. Hal ini dapat dicapai karena harga jual jasa reparasi berdasarkan metode time and material lebih rendah jika dipakai oleh perusahaan

3. Jika kapasitas penggunaan jam jasa reparasi tidak dapat digunakan sampai pada kapasitas maksimal sebaiknya perusahaan mengurangi pemakaian tenaga kerja langsung. 


\section{DAFTAR PUSTAKA}

Bastian, Bustami \& Nurlela. (2016). Akuntansi Biaya : Teori dan Aplikasi. Yogyakarta: Penerbit Graha Ilmu

Boone,L.,E \& Kurtz. (2013). Pengantar Bisnis Kontemporer. Edisi 13, Jilid 2. Jakarta : Salemba Empat.

Carter, W.K. (2009). Akuntansi Biaya. Edisi 14, Jilid 1. Jakarta: Salemba Empat

Prawironegoro, D., Utari, D., \& Purwanti, A. (2016). Akuntansi Manajemen. Edisi 4. Jakarta: Mitra Wacana Media

Firdaus, A. D. (2012). Akuntansi Biaya. Edisi 3. Jakarta :Salemba Empat.

Giri, E. F.(2012). Akuntansi Keuangan Menengah 1.Yogyakarta: Penerbit UPP STIM YKPN.

Harahap, S. S. (2011). Teori Akuntansi. Edisi Revisi 2011. Jakarta : Rajawali Pars

Horngren, C. T., George, F. \& Datar, S. M. (2008). Akuntansi Biaya: Penekanan Managerial. Terjemahan D. Andriani. Edisi 12, Jilid 1. Jakarta : Salemba Empat

Kotler, P., \& Keller, K., L. (2004). Manajemen Pemasaran. Jilid 1. Jakarta : Indeks

Mulyadi. (2012). Akuntansi Biaya . Edisi kelima.Yogyakarta : UPP STIM YKPN

Mulyadi. (2001). Sistem Akuntansi. Jakarta : Salemba Empat

Mursyidi. (2009). Akuntansi Biaya: Conventional Costing, Just In Time, dan Activity- Based Costing. Bandung : Refikan Aditma

Pontoh, W., \& Budiarso, N. S. (2018). Ipteks penerapan metode penentuan harga jual normal dalam penentuan harga jual jasa (Studi kasus pada usaha photocopy Gloria Manado). Jurnal ipteks akuntansi bagi masyarakat, 02(01), 21-30. DOI: https://doi.org/10.32400/jiam.2.1.2018.23523.

Rudianto. (2013). Akuntansi manajemen: Informasi untuk pengambilan Keputusan Strategis. Jakarta : Erlangga.

Swastha, B. (2010). Manajemen penjualan. Edisi 13. Yogyakarta : BPFE

Witjaksono, A.(2006). Akuntansi Biaya. Jakarta : Graha Ilmu 